\section{'Shuswap' Strawberry}

\author{
Hugh A. Daubeny \\ Research Station, Agriculture Canada, 6660 N.W. Marine Drive, \\ Vancouver, B.C. V6T 1X2, Canada
}

\section{P.P. Moore and T.M. Sjulin ${ }^{1}$ \\ Puyallup Research and Extension Center, Washington State University, Puyallup, WA 98371}

\section{F.J. Lawrence $^{2}$ \\ U.S. Department of Agriculture-Agricultural Research Center, Department of Horticulture, Oregon State University, Corvallis, OR 97331}

\section{B.H. Barritt \\ Washington State University Tree Fruit Research Center, Wenatchee, WA 98801}

Additional index words. Fragaria $\times$ ananassa, fruit breeding, fresh market, virus tolerance, winter hardiness

'Shuswap' (Fig. 1) is a new strawberry $($ Fragaria $\times$ ananassa) cultivar released from the breeding program at the Agriculture Canada Research Station, Vancouver, B.C. In trials throughout the Pacific Northwest, it has produced high yields of firm, large, glossy, light red fruit with some resistance to Botrytis cinerea Pers. ex Fr. The fruit appears better suited for the fresh market than 'Totem', the leading Pacific Northwest cultivar (Lawrence, 1989), and other cultivars grown in the region. 'Shuswap' plants are relatively winter hardy and are virus tolerant, traits that will contribute to planting longevity. 'Shuswap' is the name of an interior British Columbia Indian tribe for which a well-known lake in the North Okanagan district of British Columbia is named. The name was chosen because the cultivar performed well in a grower trial in that district.

\section{Origin}

'Shuswap' (tested as BC 76-7-20) was selected in 1977 by H.A.D. from a 1976 cross made by B. H. B. (at the Washington State
Univ., Puyallup Research and Extension Center) between 'Holiday' and Washington State Univ. selection 1651 (Fig. 2). 'Shuswap' has been tested extensively throughout the Pacific, Northwest in research plots and in grower trials.

\section{Performance and description}

Peformance data comparing 'Shuswap' with other Pacific Northwest cultivars, including 'Redcrest', a new release from the Oregon State Univ.-U.S. Dept. of Agriculture breeding program, were obtained from trial plantings at Abbotsford, B.C. (Table 1). These data are typical of those obtained from other trial plantings in the Pacific Northwest. The plantings, established from certified plants, were made in 1986 and 1987. Data from the 1986 planting were obtained only in 1987, whereas data from the 1987 planting were obtained from the first and second fruiting years, 1988 and 1989, respectively. In each planting, a cultivar was represented by a 6-m matted row replicated four times.

In 1987, 'Shuswap' had higher yields than
'Hood' or 'Shuksan' and similar yields to other cultivars, including 'Totem' (Table 1). Mean fruit weight of 'Shuswap' was similar to that of 'Totem', 'Northwest', 'Rainier', and 'Sumas' and higher than that of 'Benton', 'Hood', 'Redcrest', and 'Shuksan'. In 1988, 'Shuswap' yielded the same as 'Totem' and 'Redcrest' and less than 'Sumas'; fruit weighed the same as 'Totem' and 'Sumas' and more than 'Redcrest'. The low yields and reduced fruit weights in 1989 were due to extensive winter injury following freezes of $-15 \mathrm{C}$ (2 Feb.). The performance of 'Shuswap' was similar to 'Totem'; yields and fruit weight were lower than for 'Sumas' and 'Redcrest'. 'Shuswap' appears to have a level of winter hardiness similar to 'Totem' and less than 'Sumas'. 'Totem' is recognized as being relatively winter hardy in the Pacific Northwest (Lawrence, 1989).

In the first fruiting year of a 1986-planted trial at Puyallup, Wash., the performance of 'Shuswap' was similar to that at Abbotsford with yields similar to those of 'Totem' and 'Benton' and higher than for 'Hood' and 'Shuksan' (data not presented). 'Redcrest' had higher yields than 'Shuswap'. In 1989, at the same location, after freezes of $-13 \mathrm{C}$ (3 Feb.), 'Shuswap' yielded the same as 'Totem' and 'Sumas' and more than 'Shuksan', 'Benton', 'Olympus', and 'Hood'. These relationships are further evidence of the relative winter hardiness of 'Shuswap'.

'Shuswap' has also been tested in a 1986planted trial at the North Willamette Research and Extension Center, Aurora, Ore. In 1987, its yield was similar to that of 'Sumas' and 'Totem' and higher than that of 'Redcrest' and 'Shuksan' (data not presented).

'Shuswap' plants are vigorous and produce abundant runners in the planting year and subsequently. Petioles, which are green and often have a red tinge, are relatively long and hold the medium green leaves in a slightly spreading habit. Most flowers are at or below the leaf canopy and are produced on erect to semi-erect peduncles, many of which do not fall to the ground as the fruit matures.

The fruit are large, as judged by their weight (Table 1), globose conic, smooth and

Received for publication 23 Jan. 1990. We acknowledge the assistance of the following persons in testing 'Shuswap': A.K. Anderson, Agriculture Canada, Research Station, Vancouver, B.C.; T.E. Baumann, Fraser Valley Strawberry Growers Assn., Clearbrook, B.C.; L.W. Martin, North Willamette Research and Extension Center, Aurora, Ore.; R.A. Norton, Washington State Univ., Mt. Vernon; W.S. Peters, B.C. Min. of Agriculture and Fisheries, Abbotsford; W.A. Sheets, Oregon State Dept. of Agriculture, Hillsboro; B. Warner, B.C. Min. of Agriculture and Fisheries, Sidney. The cost of publishing this paper was defrayed in part by the payment of page charges. Under postal regulations, this paper therefore must be hereby marked advertisement solely to indicate this fact.

'Current address: Driscoll Strawberry Assocs., 404 San Juan Rd., Watsonville, CA 95076.

${ }^{2}$ Current address: USDA-ARS National Clonal Germplasm Repository, 33447 Peoria Rd., Corvallis, OR 97333

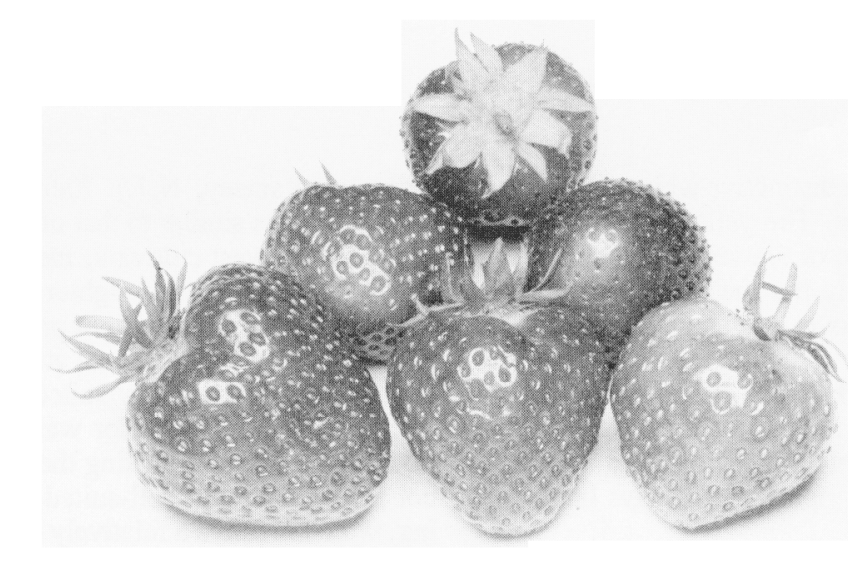

Fig. 1. 'Shuawap' strawberry. 
Table 1. Performance of 'Shuswap' and other strawberry cultivars in matted rows at Abbotsford, B.C. ${ }^{\text {Z. }}$

\begin{tabular}{|c|c|c|c|c|c|c|c|c|c|}
\hline \multirow[b]{2}{*}{ Cultivar } & \multicolumn{3}{|c|}{$\begin{array}{l}\text { Marketable yield } \\
\text { (kg/6 m plot) }\end{array}$} & \multicolumn{3}{|c|}{ Wt (g/fruit) } & \multicolumn{3}{|c|}{ Preharvest Botrytis (\%) } \\
\hline & 1987 & 1988 & 1989 & 1987 & 1988 & 1989 & 1987 & 1988 & 1989 \\
\hline Shuswap & $13.1 \mathrm{a}$ & $15.6 \mathrm{~b}$ & $1.3 \mathrm{c}$ & $13.3 \mathrm{a}$ & $13.3 \mathrm{a}$ & $5.0 \mathrm{~b}$ & $3.5 \mathrm{c}$ & $6.5 \mathrm{~b}$ & $2.3 \mathrm{c}$ \\
\hline Totem & $14.4 \mathrm{a}$ & $15.0 \mathrm{~b}$ & $2.5 b c$ & $13.3 \mathrm{a}$ & $12.8 \mathrm{ab}$ & 5.6 & $5.0 \mathrm{c}$ & $5.5 \mathrm{~b}$ & $6.9 \mathrm{~b}$ \\
\hline Benton & $12.3 \mathrm{a}$ & & & $10.4 b c$ & & & $5.2 \mathrm{c}$ & & \\
\hline Hood & $7.0 \mathrm{~b}$ & & & $9.2 \mathrm{c}$ & & & $10.1 \mathrm{abc}$ & & \\
\hline Northwest & $14.8 \mathrm{a}$ & & & $11.7 \mathrm{ab}$ & & & $16.4 \mathrm{a}$ & & \\
\hline Redcrest & $14.9 \mathrm{a}$ & $14.7 \mathrm{~b}$ & $3.7 \mathrm{ab}$ & $10.2 \mathrm{bc}$ & $12.0 \mathrm{~b}$ & $7.2 \mathrm{a}$ & $6.6 \mathrm{bc}$ & $8.8 \mathrm{~b}$ & $7.2 \mathrm{~b}$ \\
\hline Rainier & $11.8 \mathrm{a}$ & & & $12.9 \mathrm{a}$ & & & $10.2 a b c$ & & \\
\hline Shuksan & $7.3 \mathrm{~b}$ & & & $9.7 b c$ & & & $16.9 \mathrm{a}$ & & \\
\hline Sumas & $14.5 \mathrm{a}$ & $19.0 \mathrm{a}$ & $4.9 \mathrm{a}$ & $13.1 \mathrm{a}$ & $13.6 \mathrm{a}$ & $8.2 \mathrm{a}$ & $14.7 \mathrm{ab}$ & $13.8 \mathrm{a}$ & $15.3 \mathrm{a}$ \\
\hline
\end{tabular}

${ }^{2}$ Each cultivar was represented by four replications in each of two plantings made in 1986 and in 1987 , respectively. Fruit was harvested from the 1986 planting in 1987 and from the 1987 planting in 1988 and 1989.

yean separation within columns by Duncan's multiple range test, $P=0.05$.

Table 2. Fruit firmness (N) of 'Shuswarp' and other strawberry cultivars at Abbotsford, B.C., and Puyallup, Wash. ${ }^{2}$

\begin{tabular}{lcccccc}
\hline \hline & \multicolumn{3}{c}{ Abbotsford } & & \multicolumn{2}{c}{ Puyallup } \\
\cline { 2 - 3 } \cline { 6 - 7 } Cultivar & $1987^{\mathrm{y}}$ & $1988^{\mathrm{x}}$ & $1989^{\mathrm{y}}$ & & $1987^{\mathrm{w}}$ & $1988^{\mathrm{w}}$ \\
\hline Shuswap & $3.25 \mathrm{a}$ & $3.20 \mathrm{a}$ & $2.89 \mathrm{a}$ & & $3.34 \mathrm{a}$ & $3.15 \mathrm{a}$ \\
Benton & $2.29 \mathrm{~b}$ & $1.96 \mathrm{~b}$ & & & $1.96 \mathrm{~d}$ & $1.86 \mathrm{de}$ \\
Hood & $2.27 \mathrm{~b}$ & & & & $2.36 \mathrm{c}$ & $2.06 \mathrm{~cd}$ \\
Olympus & & & & & $1.67 \mathrm{e}$ & $1.78 \mathrm{e}$ \\
Redcrest & & $3.14 \mathrm{a}$ & & & $2.97 \mathrm{~b}$ & $3.10 \mathrm{a}$ \\
Shuksan & & & & & $2.46 \mathrm{c}$ & $2.18 \mathrm{c}$ \\
Sumas & $2.33 \mathrm{~b}$ & $2.10 \mathrm{~b}$ & $2.29 \mathrm{~b}$ & & $2.41 \mathrm{c}$ & $2.20 \mathrm{c}$ \\
Totem & $2.63 \mathrm{~b}$ & $3.10 \mathrm{a}$ & $2.54 \mathrm{ab}$ & & $2.41 \mathrm{c}$ & $2.54 \mathrm{~b}$ \\
\hline
\end{tabular}

${ }^{2}$ Mean separation, within columns, by Duncan's multiple range test, $P=0.05$.

${ }^{y}$ Mean of 10 fruit harvested on each of three dates.

'Mean of 10 fruit harvested on each of four dates.

wean of five fruit from each of four replications on four or five harvest dates.

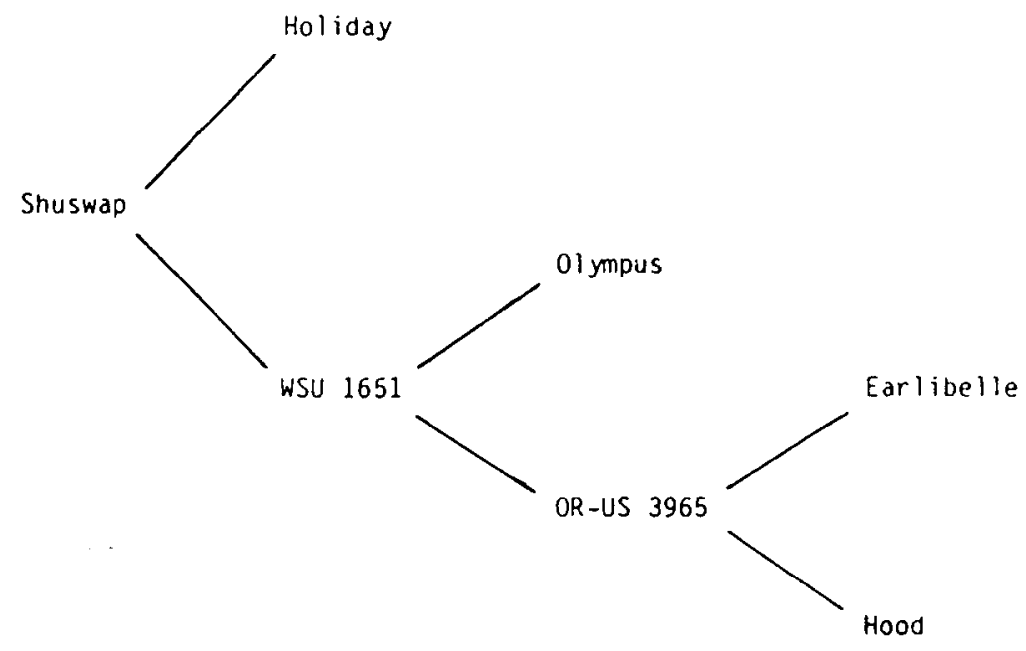

Fig. 2. Pedigree of 'Shuswap' strawberry.

uniform, with a distinctive white area around a reflexed calyx. The yellow achenes are at the fruit surface or are slightly sunken. The fruit picks easily but the calyx is relatively difficult to remove, a desirable trait for fruit destined for the fresh market but not for the processing market.

The ripening season of 'Shuswap' has varied from the same as 'Totem' to several days later; it usually ripens 3 or 4 days later than 'Sumas'.

Fruit color of 'Shuswap' was measured with a Minolta CR-200b Chroma Meter
Hatfield, Pa.), was determined for fruit of 'Shuswap' and other cultivars at Abbotsford in 1987, 1988, and 1989, and at Puyallup in 1987 and 1988 (Table 2). At Abbotsford in 1987, 'Shuswap' fruit was firmer than that of any other cultivar tested. In 1988, 'Shuswap' fruit was firmer than 'Benton' and 'Sumas' but not 'Totem' or 'Redcrest', and in 1989 it was similar to 'Totem' and firmer than 'Sumas'. At Puyallup in 1987, 'Shuswap' had firmer fruit than the other Pacific Northwest cultivars tested and in 1988 had firmer fruit than all but 'Redcrest'. Further evidence of the high level of firmness of 'Shuswap' fruit was obtained from the Aurora trial in which it produced firmer fruit than 'Totem', 'Redcrest', 'Shuksan', or 'Sumas' (data not presented).

At Abbotsford in 1988 and 1989, the percent soluble solids concentration (SSC) of 'Shuswap' $(6.5 \%)$ fruit was less than that of either 'Totem' $(7.4 \%)$ or 'Sumas' $(7.2 \%)$. In 1987, there were no differences among the cultivars in SSC (range $7.7 \%$ to $8.2 \%$ ). Compared to other years, the 1987 fruiting season had considerably more hours of sunshine and higher mean temperatures, factors known to increase SSC (Sistrunk and Moore, 1971). Fruit of 'Shuswap' from the Abbotsford plantings usually has a mild subacid flavor that is considered acceptable for the fresh market. At other locations (North Okanagan in British Columbia and Aurora in Oregon), where hours of sunshine and mean temperatures are usually higher than at Abbotsford, the fruit is sweeter and less acid in taste. This suggests that under these conditions, the sugar : acid ratio may have influenced flavor.

Acidity, as measured by total acids and $\mathrm{pH}$, of 'Shuswap' fruit was determined only in 1989 at Abbotsford; there were no differences in comparisons with 'Totem' and 'Sumas'.

\section{Pest responses}

In the Abbotsford planting, the level of tolerance to the aphid-borne virus complex that infects Pacific Northwest strawberries was similar for 'Shuswap', 'Totem', and 'Sumas'. Both 'Totem' and 'Sumas' have been recognized as showing higher tolerance levels than other Pacific Northwest cultivars including 'Benton', 'Hood', 'Olympus' 'Rainier', and 'Shuksan' (Daubeny, 1987).

In 1987, 'Shuswap' showed similar reactions to preharvest fruit rot caused by $\mathrm{B}$. $\mathrm{ci}$ nerea as 'Totem' and several other Pacific Northwest cultivars (Table 1). In 1988, it also showed a similar reaction to 'Totem' but in 1989, it had less rot. In all comparisons, 'Shuswap' had less preharvest rot than 'Sumas', which is recognized as relatively susceptible (Daubeny, 1987). In postharvest tests done in 1989 according to the method described by Daubeny and Pepin (1977), 'Shuswap' showed significantly less $B$. $c i$ nerea rot than 'Totem' in one of four tests and significantly less than 'Sumas' in all four tests (data not presented).

'Shuswap' is slightly susceptible to leaf 
spot, caused by Mycosphaerella fragariae (Tul.) Lindau, and to powdery mildew, caused by Sphaerotheca macularis (Walk. ex. Fr.) Mgn. The latter has not been observed on fruit.

Information on the reaction of 'Shuswap' to two-spotted spider mite, Tetranychus urticae Koch., is limited. However, in 1977. the year it was selected, there was extensive damage due to mites throughout the strawberry trial plantings at Abbotsford. It showed little damage compared to many adjacent genotypes and rated 4 on a 1 to 5 scale with 1 indicating extreme damage and 5 indicating no evidence of damage.

Unlike 'Totem', 'Shuswap' was not selected in the seedling stage for resistance to red stele root rot, caused by Phytophthora fragariae Hickman, and, unlike 'Sumas', it has not been screened for reaction to individual races of the organism (Daubeny, 1987). In three of four trial situations in which the disease was present, 'Shuswap' was susceptible.

\section{Adaptability and use}

'Shuswap' appears to be well-adapted for use throughout the Pacific Northwest. It meets the requirements for a main season freshmarket cultivar with firm, glossy, and relatively light red fruit with some resistance to fruit rot. These traits likely contribute to an extended shelf life compared to that of other cultivars currently grown in the region. It is not recommended in situations in which red stele might be present. Adaptation outside the Pacific Northwest has not been determined.

\section{Availability}

The names of propagators with certified 'Shuswap' plants will be supplied by H.A.D. on request.

\section{Literature Cited}

Daubeny, H.A. 1987. 'Sumas' strawberry. HortScience 22:511-513.

Daubeny, H.A. and H.S. Pepin. 1977. Evaluation of strawberry clones for fruit rot resistance. J. Amer. Soc. Hort. Sci. 102:431-435.

Lawrence, F.J. 1989. Pacific Northwest strawberry cultivars. Fruit Var. J. 43:19-21.

Sistrunk, W.A. and J.N. Moore. 1971. Strawberry quality studies in relation to new variety development. Ark. Agr. Expt. Sta. Bul. 761. 